\title{
Government Ownership and the Maritime Lien
}

\author{
(To L. E.)
}

I.

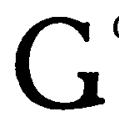

OVERNMENT ownership and operation of merchant vessels is a matter of great importance to those who, in dealing with such vessels willingly or unwillingly, become the possessors of claims which formerly could have been speedily enforced in the courts against private individuals and their vessels. Men whose relation to public carriers is confined to safe rides as a passenger may cry for government ownership, but not necessarily the man who finds he has that government for debtor. While his claims have in fact and so far as possible been settled on the same basis that a private individual might have settled, nevertheless if there is a change in policy there develops toward hin the usual bureaucratic attitude of governments in business, and his position nay be a hard one, particularly in England and the United States, where the theory that the State cannot be sued and is not accountable for its acts is strongly entrenched in the legal system. Indeed, it is not improbable that the absence of a prompt and expeditious remedy may deter the shipper from shipping his goods on government vessels, the sailor from signing articles for service upon them, the salvor from salving them, the charterer from chartering them, and the chandler and repairer from supplying and repairing them on any but disadvantageous terms; while he whose ship is in collision with a government merchant ship, will be even worse off, for he cannot avoid the thing that runs him down. So far as is possible, these men will very likely turn to private vessels, including those of foreign competing nations, where such a remedy still exists, particularly in the suitable and compelling form of the maritime lien or right in rem.

It is true that Mr. Hurley has recently announced a programme conteinplating a form of private ownership. ${ }^{1}$ Vessels constructed by the Emergency Fleet Corporation and now owned by the United States are to be sold to American citizens, payment to be made in annual installments, with unpaid balances secured by a inortgage to the United States, which is to be

1 The Nautical Gazette, March 29, 1919, pp. 220, 213. 
represented on the board of directors of the purchasing company, and is to have power to prescribe the routes over which the vessel is to be operated. But it is hinted that a change in the law may be sought in order to give mortgages precedence, not now existing, over the ordinary maritime lien so that they may be more attractive to investors. In any event, since the scheme may meet the objection of those who advocate government ownership, as well as those believing in private ownership pure and simple, there is a doubt whether or not it or its equivalent will be adopted for a long time.

It is easy enough to pronounce as Judge Mayer has done in the Maipo:" "It is said great loss and inconvenience may be visited upon the many kinds of people who deal with a vessel thus immune, and that American citizens will be put to the trouble and expense for claims, large and small, of seeking their relief in far-distant foreign jurisdictions. The answer is that, when one knows with whom he is dealing and the law applicable, he must arrange accordingly. This may be difficult, but in these days of rapid changes, accommodation to new conditions is accomplished effectively and expeditiously." While this was said with reference to foreign owned vessels, nevertheless American citizens may also have to "arrange accordingly" with vessels of their own government. If their remedies are not clear, they may so arrange, either by not dealing with such vessels at all, or by refusing to give credit, or by making high charges, when in a position to do so, to discount the imperfect remedy. None of these practices are particularly favorable to the growth of commerce and a merchant marine. However, the matter is arranged, those who must deal with government vessels may be, as a practical matter, in an extremely difficult situation, particularly if a prophecy of this same Judge ${ }^{3}$ becomes universally true: "Indeed, it would not be surprising if at no distant date large numbers of vessels setting out from various ports of various countries would be manned as government vessels for the very purpose of assuring quick clearance and freedom from process."

It is outside my purpose to consider the broad question of a State's liability.4 All I shall attempt will be an exposition of the

2 (So. Dist. N. Y., 1918) 252 Fed. 627, 630.

3 Idem, p. 631, but cf. the court's view in The Attualita (Circ. Ct. App., 4th Circ., 1916) 152 C. C. A. 43, 238 Fed. 909, and in The Crimdon (Prob. Div., 1918) 35 T. L. R. 81.

'See on this subject a very instructive article which, in spite of 
present law as to the existence and enforceability of the maritime lien on government-owned and operated merchant vessels of the United States, and then to an examination of some of the theories advanced. It will appear that the existing law is incomplete, confused, and unprepared to meet the problem, which has come to us together with our new merchant fleet, still governmentowned, and perhaps permanently so,-at least in part. The clarification of the situation, by legislation if necessary, is one of the many duties of readjustment before us, and this article is written in the hope that it may at least stimulate an interest in a solution.

That the question is an important one is shown by certain recent cases. ${ }^{5}$ It is true that in most of these a vessel of a foreign friendly power was concerned, but the decisions are important, for the courts have often treated the matter no differently than they would have done if the vessel were one of our own. And, furthermore, cases involving our own ships are now pending in the Supreme and District Courts. ${ }^{\circ}$

What, then, is the present state of the law in the United States as to the existence and enforceability of a maritime lien upon a government-owned merchant vessel? In other words, is the shipper, the sailor, the salvor, the charterer, the chandler, the ship-repairer, and the host of others who deal with ships, without the rights he formerly had?

its title, refers to decisions in the United States: Laski, The Responsibility of the State in England, 32 Harvard Law Review, 447; and see also, covering somewhat the same ground as the present article, Charles $\mathrm{H}$. 'Weston, Actions Against the Property of Sovereigns, 32 Harvard Law Review, 266, for an analysis of many of the cases here referred to.

5 The Roseric (Dist., N. J., 1918) 254 Fed. 154; The Maipo, supra, n. 2; The Pampa (E. Dist. N. Y., 1917) 254 Fed.' 137; The Attualita, supra, n. 3; The Johnson Lighterage Co. No. 24 (Dist. N. J., 1916) 231 Fed. 365; The Luigi (E. Dist. Pa., 1916) 230 Fed. 493. For a discussion of this subject see Charles $N$. Gregory, Jurisdiction over Foreign Ships in Territorial Waters, 2 Michigan Law Review, 333, 337; also note, 24 Harvard Law Review, 489. Cf. The Athanasios (So. Dist. N. Y., 1915) 228 Fed. 558, and The Florence H. (So. Dist. N. Y., 1918) 248 Fed. 1012, this last being the only case against an American merchant vessel of the United States and depending on a questionable interpretation of the Shipping Act; $\$ 9$ (Act of September 7, 1916, ch. 451, 39 U. S. Stats. at I. 728.)

(A decision, too recent to be verified before this article goes to press, is reported to have been rendered by Judge Bean in the United States District Court, Oregon, holding that a merchant vessel built for the United States by a private builder under contract with the Emergency Fleet Corporation, and' still in the builder's possession, cannot be attached. The Portland Journal, April 22, 1919. 


\section{II.}

It is clearly settled that a public armed vessel of a State whether domestic or foreign, cannot be seized upon a libel for collision, ${ }^{7}$ or for salvage ${ }^{8}$ or other maritime cause. ${ }^{9}$ This rule has also been applied in the case of a vessel used as an admiralty transport, possibly only for cargo and not for troops, ${ }^{10}$ and to a military vessel engaged in carrying supplies to the army and transporting troops, not a part of the navy, but operated wholly by the War Department.11 So far all is clear enough, but when we come to vessels not actively engaged in connection with navy or army, but used by the government for some other governmental purpose, the matter is not so clear. It has been held that a vessel intended to be used as a revenue cutter may be libeled for salvage, ${ }^{12}$ or for materials and supplies. ${ }^{13}$ On the other hand, with regard to vessels owned and operated by municipal corporations, no libel was permitted of a vessel used to transport pris-

7 The Pizarro v. Matthias (So. Dist. N. Y., 1852) 10 N. Y. Obs. 97, Fed. Cas. No. 11,199; The Parlement Belge (1880) L. R. 5 Prob. Div. 197, 205, 207, dicta. Cf. The Athol (High Ct. Adm. 1842) I Wt. Rob. 374, a troop ship, and The Pampa, supra, n. 5 , a transport of the Argentine Navy manned by members of the naval forces, engaged in carrying cargo for private persons at the time of the collision.

8 The Constitution (1879) L. R. 4 Prob. Div. 39; The Prins Frederik (High Ct. Adm. 1820) 2 Dods. 451. Cf. The Alexander (High Ct. Adm. 1815) 2 Dods. 37. Salvage may be recovered under the Tucker Act; (Act of March 3, 1887, ch. 359, 24 U. S. Stats. at L. 505. See Judicial Code (1911) $\$ \S 24$, par. 20, 145.) Hartford Trans. Co. v. United States (Circ., Dist. Conn., 1905) 138 Fed. 618.

${ }^{2}$ Domestic vessels, Moitez v. The South Carolina (Adm. Pa., 1781) Bee 422, Fed. Cas. No. 9, 697; foreign vessels, The Cassius (1796) 2 Dall. 365, 1 L. Ed. 418; The Exchange (1812) 7 Cranch. 116, 3 L. Ed. 287; L'Invincible (1816) 1 Wheat. 238, 4 L. Ed. 234. Cf. The Santissima Trinidad (1822) 7 Wheat. 283, 5 L. Ed. 454 . The French law is to the same effect- "les batiments de guerre et assimilés" cannot be seized. Edmund Thaller, Traité Général Théorique et Pratique de Droit Commercial, (Droit Maritime par Georges Ripert), Paris, 1913, p. $713, \S 892$.

${ }^{10}$ The Roseric, supra, n. 5, a British vessel. S. 726 .

11 The Thomas A. Scott (Dist. N. Y., 1864) 90 Fed. 746, 10 L. T. N.

12 Long v. The Tampico (So. Dist. N. Y., 1883) 16 Fed. 491. Cf.

Five Steel Barges (1880) L. R. 15 Prob. Div. 142.

${ }_{13}$ The Revenue Cutter No. 2 (Dist. Ore., 1877) 4 Sawy. 143, Fed. Cas. No. 11,714, but the vessel had not been accepted by the United States. And see The Revenue Cutter No. 1 (Dist., No. Dist. Ohio, 1860) Brown Adm. 76, Fed. Cas. No. 11,713, where a state lien for construction was enforced without discussion of immunity as property of the United States. 
oners to jail and the sick to public hospitals, ${ }^{14}$ or of a tug and dredge engaged in dredging a municipal port, ${ }^{15}$ or of a police boat, ${ }^{16}$ or of an ice breaker used also for towing and lightering, ${ }^{17}$ but the question was perhaps considered as open in the case of a fire-boat. ${ }^{18}$ It has also been announced that a light-ship or a vessel to be used in connection with lighting a harbor were not subject to libel, 19 and as to vessels owned by the government and used for carrying the mail, it has been held that such vessels, which also carried passengers, could not be libeled for a collision. ${ }^{20}$

Now coming to vessels used purely as merchantment, we reach the gist of the matter. Liens upon merchant prizes arising out of events occurring after their capture can be enforced in the

14 The Fidelity (Circ., So. Dist. N. Y., 1879) 16 Blatchf. 569, Fed. Cas. No. 4758 .

${ }_{15}$ The John McCraken (Dist. Ore., 1906) 145 Fed. 705, but the municipal corporation is liable in personam: United States $\mathbf{v}$. Port of Portland (Dist. Ore., 1906) 147 Fed. 865. Further of the liability in personam of a municipal corporation see Barney Dumping-Boat Company v. Mayor, etc. (So. Dist. N. Y., 1889) 40 Fed. 50; Edgerton v. Mayor, etc. (So. Dist. N. Y., 1886) 27 Fed. 230. But cf. Haight v. Mayor, etc. (So. Dist. N. Y., 1885) 24 Fed. 93.

${ }_{16}$ The Protector" (Dist. Mass., 1884) 20 Fed. 207, collision, the Seneca (Dist., E. Dist. N. Y., 1876) 8 Ben. 509, Fed. Ćas. No. 12,668, wharfage. A boat owned by a state and used for policing oyster plantations was held subject to forfeiture for breach of the navigation laws. The Oyster Police Steamers of Maryland (Dist. Md., 1887) 31 Fed. 763.

${ }_{17}$ The F. C. Latrobe (Dist. Md., 1886) 28 Fed. 377, but held that the municipal corporation is liable in personam; and also so held in The Major Reybold (E. Dist. Pa., 1901) 111 Fed. 414, even though the ice boat . was at the time being used in connection with a parade of the $G$. A. R; and in City of Philadelphia v. Gavagnin (Circ. Ct. App., 3rd Circ., 1894) 62 Fed. 61 , where the ice boat was towing a vessel outside the state. Contra, Guthrie v. City of Philadelphia (Dist., E. Dist. Pa., 1896) 73 Fed. 688, dictzlm, where the ice boat was acting outside the state.

${ }_{18}$ Workman v. New York City, Mayor, Aldermen, and Commonality (1900) 179 U. S. 552, 572, 45 L. Ed. 314, 324, 21 Sup. Ct. Rep. 212, 219. But in Thompson Navigation Co. v. City of Chicago (Dist., No. Dist. IIl., 1897) 79 Fed. 984, there is 2 dictum to the effect that there is no enforceable lien. Liability in personam was decreed in these cases and in Henderson v. City of Cleveland (Dist., No. Dist. Ohio, 1899) 93 Fed. 844; Island Transp. Co. v. Seattle (Dist., W. Dist. Wash., N. D., 1913) 205 Fed. 993; City of Chicago v. White Transp. Co. (Circ. Ct. App., 7th Circ., 1917) 243 Fed. 358.

${ }_{19}$ Cf. Briggs v. The Lightboats (Mass., 1865) 11 Allen 157, to enforce a state construction lien; United States v. Morgan (Circ. Ct. App., 4th Circ., 1900) 99 Fed. 579, dictum. A claim for "extraordinary towage" of a light-ship was allowed in a proceeding under the Tucker Act, The Viola (Circ. Ct. App., 3rd Circ., 1893) 55 Fed. 829.

${ }^{20}$ Cf. The Jassy L. R. (1906) Prob. Div. 270; Young v. S. S. Scotia (1903) A.C. 501; The Parlement Belge, supra, n. 7; and see The Merchant (Dist., So. Dist. Fla., 1851) 4 Adm. Rec. 544, Fed. Cas. No. 9435, where it was held that government mail was not liable for salvage. 
condemnation proceedings, ${ }^{21}$ but not by an independent libel, ${ }^{22}$ for the obvious reason that the necessary proceeding by which their title is adjudicated would be prejudiced. In a case decided just after the civil war concerning a vessel in the service of the government and under a charter by which the government was to coal her, but the owner still to operate her, a libel in rem for a collision was sustained on the merits, no question of jurisdiction being raised, ${ }^{23}$ and a vessel under charter to the United States not amounting to a demise was held liable on a bottomry bond.24 It was specifically held in 1916 that a vessel in the possession of her owner, who was required, however, to navigate her as the government directed and to carry such cargo as it ordered at a fixed charge, could be libeled for collision. ${ }^{25}$ On the other hand, a vessel owned by the government, but chartered to a private individual and used for carrying private cargo, was held to be immune from libel. ${ }^{26}$ In a somewhat sinilar case the court proceeded on a bond given to release an attachment of a vessel privately owned and privately chartered, but declared to be in government service, and in fact engaged in carrying grain to be distributed by the governinent. The court intimated, however, that if bond had not been given the libel would have been dismissed. ${ }^{27}$ In what may perhaps be regarded as the leading case, government property, carried on a private common carrier for hire, was in a proceeding in rem held liable to pay salvage, ${ }^{28}$ and this doctrine was pressed so far 21 The Siren (1868) 7 Wall. 152, 19 L. Ed. 129.

22 The Nassau (1867) 4 Wall. 634, 18 L. Ed. 413. Cf. In re White Star Towing Co. (So. Dist. Ga., 1898) 91 Fed. 285.

${ }_{23}$ The Louisiana (1865) 3 Wall. 164, 18 L. Ed. 85; The Ticonderoga (High Ct. Adm., 1857) Swab. 215.

24 The Othello (E. Dist. N. Y., 1866) 5 Blatchf. 342, Fed. Cas. No. 10,611 .

25 The Attualita, supra, n. 3, upon which see note, 16 Columbia Law Review 672; The Messicano (Prob. Div., 1916) 32 T. L. R. 319; The Broadmayne I. R. (1916) Prob. Div. 64. A Swedish vessel, requisitioned by the United States and then chartered by its owners to the United States Shipping Board Emergency Fleet Corporation and used by the Army Transport Service was held immune from arrest. The Crimdon, supra, n. 3.

${ }_{28}$ The Maipo, supra, n. 2. Cf. The Dora and The Annette (Prob. Div., 1919) 35 T. I. R. 288 , libel in rem allowed as to vessel requisitioned by unrecognized government, and The Gagara (C. A., 1919) 35 T. L. R. 259, not allowed as to a prize captured from the Bolshevists by the Esthonian Government, "provisionally recognized."

27 The Luigi (E. Dist. Pa., 1916) 230 Fed. 493.

28 The Davis, (1869) 10 Wall. 15, 19 L. Ed. 875; The Merchant, supra, n. 20; The Qthello, supra, n. 24, holding cargo of the United States not liable on a bottomry bond placed upon it by the master of a private vessel carrying it. 
that such property was held even though it was munitions for use of the armies of a country at war. ${ }^{29}$ And Justice Story laid down that a private owner of a vessel might hold property of the government, subject to a general average contribution, against the United States. ${ }^{30}$

It would be profitless to endeavor to reconcile the foregoing cases. Some were cases where property of an allied government at war on the side of the country of the court was involved, and some were cases of foreign, and some cases of domestic ships. It is impossible to generalize upon all these cases in such a way as to formulate guiding principles, apt to settle the many questions likely to arise. As has been stated the only matter that is perfectly clear is that a public armed vessel in the possession and control of the government owning it, cannot be libeled either at home or abroad, and that probably the same rule applies to other vessels in government service, such as light ships and the like, but in the case of vessels used in the merchant service, the law is conflicting, with a strong tendency, however, in the most recent cases, to hold them immune.

Why is there this confusion? Is it not perhaps partly due to the nature of the theories that have been advanced by the courts to justify their decisions in holding for or against the lien?

\section{III.}

Against such existence or enforcement it has been said: (1) that to admit a lien would be a derogation of the dignity and independence of the sovereign $;^{31}$ (2) that the lien is merged in the right in personam, and that since no right in personam is possible against the State, therefore no lien exists to be enforced $;^{32}$

(3) that no process can issue against government property; ss $^{3}$ (4) that to permit the marshal to seize property of the govern-

${ }^{29}$ The Johnson Lighterage Co. No. 24, supra, n. 5.

30 United States v. Wilder (Circ., Dist. Mass. 1838) 3 Sumn. 308, Fed. Cas. No. 16,694. Cf. Clarke v. New Jersey Steam Navigation Co. (Circ., Dist. R. I., 1841) 1 Story 531, 542, Fed. Cas. No. 2859, dictum.

31 Austin, Province of Jurisprudence Determined, Lecture VI; $1 \mathrm{Bl}$. Comm. c. 7. See The Pizarro v. Matthias, supra, n. 7.

132 The Fidelity (Circ. Ct., So. Dist. N. Y., 1879) 16 Blatchf. 569, 573, Fed. Cas. no. 4758.

${ }^{33}$ United States v. Clarke (1834) 8 Pet. 436, 8 L. Ed. 1001; Stanley v. Schwalby (1892) 147 U. S. 508, 512, 37 L. Êd. 259, 261, 13 Sup. Ct. Rep. 418, Cf. Carr v. United States (1878) 98 U. S. 438, 25 L. Ed. 209. Cf. Young v. S. S. Scotia, supra, n. 20. 
ment would result in unseemly conflicts ${ }^{34}$ (5) that the court could not pass a valid title; (6) that since a lien implies a right to seize and hold, the allowance of a lien would admit a right to seize and hold government property, thereby diverting it from the public use to which it is devoted $;^{35}$ and (7) that the lien is an anachronism and the government can be trusted to do the right thing. ${ }^{36}$ All these theories, if literally carried out, would result in no lien in any case. It has appeared, however, that in some cases a lien has been allowed, on reasoning that limits the fourth and sixth of the theories stated above to some circumstances, and admits the existence of the lien in others. The fourth theory, denying the courts power to enforce the lien because of the likelihood of unseemly conflicts, has been himited to cases where the property in question is in the actual possession of the government; ${ }^{37}$ and the seventh theory, based on the impolicy of permitting property to be withdrawn by seizure from public use, has been declared to exclude uses that were merely commercial. ${ }^{38}$ It is obvious that the admission of any such limitations is largely a repudiation of the other five theories above stated. Certain matters should be borne in mind in considering the vital force of all these theories in their application to actual conditions, and to a certain extent they contradict each other. ${ }^{39}$

34 The Davis, supra, n. 28; United States v. Wickersham (Circ. Ct., W. Dist. Tenn., 1882) 10 Fed. 510.

35 United States v. Morgan (Circ. Ct. App., 4th Circ., 1900) 99 Fed. 570, 39 C. C. A. 374; The Roseric, supra, n. 5; The John McCraken, supra, n. 15; The Protector, supra, n. 16; The F. C. Latrobe, supra, n. 17; The Thomas A. Scott, supra, n. 11; The Seneca, supra, n. 16; The Fidelity, supra, n. 14; United States v. Cornell Steamboat Co. (1906) 202 U. S. 184, 50 L. Ed. 987, 26 Sup. Ct. Rep. 648, semble.

${ }_{38}$ The Maipo, supra, n. 2.

37 The Davis, supra, n. 28; Long v. The Tampico, supra, n. 12; The Florence H., supra, n. 5 .

38 The Charkieh (1873) L. R. 4 Ad. \& Ec. 59; Guthrie v. City of Philadelphia, supra, n. 17; The F. C. Latrobe, supra, n. 17, dictum; The Protector, supra, n. 16, dictum; City of Philadelphia v. Gavagnin, supra, n. 17; The John McCraken, supra, n. 15; In re White Star Towing Co., supra, n. 22, dictum. See Laski, The Responsibility of the State in England, 32 Harvard Law Review, 447, 468. But this theory was disapproved in The Maipo, supra, n. 2, the case of a foreign owned vessel under a naval captain, and in The Florence $H$., supra, n. 5, dictum. The distinction here stated bears a resemblance to that between the demesnal and patrimonial property of a state in Continental legal systems.

${ }_{39}$ Cf. Workman v. New York City, etc. (1900) 179 U. S. 552, 570, 45 L. Ed. 314, 324, 21 Sup. Ct. Rep. 212, 219, where Mr. Justice White says: "... in the maritime law, the public nature of the service upon which a vessel is engaged at the time of her commission of a maritime 
(1) How far is there real, as distinguished from verbal, force in the argument that to admit a lien is a derogation of the dignity and independence of the severeign $?^{40}$ So far as the dignity of the sovereign is concerned, this is the same problem as that presented when the State is named defendant in the ordinary action in personam, though perhaps from the point of view of the administration there is greater indignity in coming into court to claim property in the possession of the judiciary, than merely to appear to fight against a judgment which it need not pay. But the courts are just as much servants of the people as the administration, and is not their dignity quite as important? It is certainly an indignity to them to be compelled to slam their doors in the faces of those who are injured. The State should not be a despot with a touchy dignity to uphold. The extreme view is expressed in the language of Mr. Justice Holmes in the case of Kawananakoa v. Polyblank," where he says, "A sovereign is exempt from suit, not because of any formal conception or obsolete theory, but on the logical and practical ground that there can be no legal right as against the authority that makes the law on which the right depends. 'Car on peut bien recevoir loy d'autruy, mais il est impossible par nature de se donner loy.' Bodin Republique, 1, chap. 8, ed. 1629, p. 132; Sir John Eliot, de Jure Maiestatis, c. 3. Nemo suo statuto ligatur necessitative. Baldus, De Leg. et Const. Digna Vox, (2 ed. 1496, fol. 5 lb, ed. 1539, fol. 61.)." While no lien was here claimed, the principle has actuated the courts in cases involving the right in rem against property of the sovereign. ${ }^{22}$ But the government has power to do the fair thing to those it injures and has in fact done so. Does anyone believe it to be any derogation of the dignity and independence of the United States that just claims are enforced

tort affords no immunity from liability in a court of admiralty where the court has jurisdiction", with United States v. Cornell Steamboat Co (1906) 202 U. S. 184, 190, 50 L. Ed. 987, 990, 26 Sup. Ct. Rep. 648, 649, where Mr. Justice Brown says: “. . . both in England and in this country, vessels belonging to the United States or to a foreign sovereign, and engaged in public service, are exempt from seizure."

40 See on this subject Laski, The Responsibility of the State in England, 32 Harvard Law Review, 447, and United States v. Lee (1882) 106 U. S. 196, 206, 27 L. Ed. 171, 176, 1 Sup. Ct. Rep. 240, 248. Cf. Walker v. United States (Circ. Ct., M. D. Ala., 1905) 139 Fed. 409, 413 , and the dissenting opinion of Mr. Justice Harlan in Belknap v. Schild (1896) 161 U. S. 10, 28, 40 L. Ed. 599, 605, 16 Sup. Ct. Rep. 443,449 .

41 (1907) 205 U. S. 349, 51 L. Ed. 834, 27 Sup. Ct. Rep. 526.

42 Cf. Young v. S. S. Scotia, supra, n. 20; Long v. The Tampico, supra, n. 12. 
against it under the Tucker Act? ${ }^{43}$ The very existence of the Act in question and the large number of suits that have been settled under it, have not resulted in the United States becoming any less dignified or independent in the eyes of its citizens or of the world. Furthermore, in foreign countries the sovereign is often accountable in the courts, ${ }^{44}$ or in other words and to avoid the lurid langnage which is frequently employed to express this theory, citizens of the State have rights when they are injured through the operation of the machinery of their government. No one thinks of these countries as undignified. Nor does the dignity of the crown of England suffer because jurisdiction to enforce claims to salvage against, ${ }^{45}$ or a general average contribution from, ${ }^{48}$ property of the Crown has been given by consent.47

But the best criticism to this theory is to be found in the decisions of the courts. The lien has been regarded as existing, though sometimes unenforceable. ${ }^{48}$ The exponents of admiralty law have not felt the same obligation towards various sovereigns as those of the common law in its later developments, and have admitted the right and sometimes the remedy. The langnage of Mr. Justice Miller, in a salvage case of government property, is worthy of quotation: "We are quite satisfied .... that it should be held to bear its share of the burden which the unani-

13 Act of March 3, 1887, c. 359, 24 U. S. Stats. at L. 505. Also, infra, n. 73 .

1s E. g. France; Frederick P. Walton, The French Administrative Courts and the French Law as to the Responsibility of the State for the Faults of its Officials: A Coniparison with the Common Law, 13 Illinois Law Review, 63. Cf. Italy; Codice di Commercio (1882) Art. 7; Errera,Traité de Droit Public Belge, p. 287, § 194.

45 The Lord Nelson (High Ct. Adm., 1809) Edw. Adm. 79; The Marquis of Huntly (High Ct. Adm., 1835) 3 Hagg. Adm. 246. Cf. Pyman S. S. Co. v. Lords Conimissioners of the Admiralty [1918] $1 \mathrm{~K}$. B. 480, affirmed (A. C., 1918) 88 L.J. K. B. 277.

${ }_{48}$ Cf. Brown v. Stapylton (C.P. 1827) 4 Bing. 119, 130 Eng. Rep. R. 713.

47 It has been stated that there is in the United States no officer wbo can give jurisdiction by consent, The Davis, supra, n. 28; United States v. Lee, supra, n. 40; United States v. New York and Oriental S. S. Co., 216 Fed. 61, 67, 132 C. C. A. 305. But cf. The Siren, supra, n. 21, and see that case for the English practise of consent giving. And see The Protector, supra, n. 16, with reference to consent by a municipal corporation.

${ }_{48}$ The Davis, supra, n. 28; Long v. The Tampico, supra, n. 12; The Siren, supra, n. 21, dictum. Cf. The St. Jago de Cuba (1824) 9 Wheat. 409, 6 L. Ed. 122; Briggs v. The Lightboats, supra, n. 19; Workman v. New York City, Mayor, Aldermen, and Conimonality, supra, n. 39; The John McCraken, supra, n. 15; The Protector, supra, n. 16; The F. C. Latrobe, supra, n. 17; The Avon (Circ. Ct., No. Dist. Ohio, 1873) Brown 
mous voice of maritime nations imposes on all other property in like condition." 49 Has not every case where the lien was enforced as in the case from which this quotation comes, and every case where it was not enforced but was declared to exist, rendered the theory ridiculous? Is there not greater indignity to the State in being declared a debtor as to its property, even though it cannot be compelled to pay, than in being declared no debtor at all?

In referring to this theory in connection with the maritime lien, however, it should be noticed that the propounders of State immunity speak not alone of the sovereign's dignity but of its independence as well. If by "independence" is meant an equivalent of dignity, a freedom from the trouble and vexation of litigation, then all that has been said in criticism here and elsewhere seeins justified. But if by "independence" is meant freedom of the administration to perform public service a different question is presented, which will be discussed later. Very likely in many cases this last idea was in the judicial mind, but draped in language appropriate to the divine right of kings.

(2) It has been stated that the lien is merged in the right in personam, and since no right in personam exists against the state, therefore, no lien exists to be enforced..$^{50}$ Assuming that there is no right in personam against the state, it does not necessarily follow that there can be no lien. In addition to what has already been said, ${ }^{51}$ it is to be remembered that a lien may exist independently of a right in personam in certain cases of salvage, ${ }^{52}$ that it has been held that even though there is no fault on the part of the owner of the vessel, the vessel may still be sued. ${ }^{53}$ Indeed, the existence of a lien and the enforcement of a right in personam are independent matters, and there is nothing so peculiar to a case where a state is the owner of the property in question as to result in a merger in this case and not in another.

Adm. 170, Fed. Cas. No. 680, semble. Cf. United States v. Lee, supra, n. 40. Cf. United States v. Cornell Steamboat Co., supra, n. 39; The Florence H., supra, n. 5, dictum.

49 The Davis, supra, n. 28.

50 The Fidelity, supra, n. 14.

61 Supra, n. 48. dictum.

52 The Emblem (Dist. Me., 1840) 2 Ware 68, Fed. Cas. No. 4434, ${ }^{33}$ The China (1868) 7 Wall 53, 19 L. Ed. 67. 
(3) In cases of non-maritime nature, it has been often stated that no process can issue against government property. ${ }^{54}$ The answer to this argument is the simple one, that in maritime cases process has in fact been issued against such property.

(4) It is also said that to permit the marshal to seize property of the government would result in unseemly conflicts between two branches of the government, ${ }^{55}$ but, as has already been noticed, ${ }^{56}$ this statement has also been modified so as to apply only to cases where government property is in the actual possession of the government. There is no greater likelihood of an unseemly conflict in cases where the property is in the hands of the government than in the many cases where the courts have issued to officials writs of mandamus, habeas corpus and the like, and in those where they have declared invalid a revenue or similar law. The officials concerned could with just as much show of right object to the decision of the court, as could government officials or employees, or men under contractual obligation to the government, raise objections when ordered by other government officials to deliver up property in their possession. Once the power of the marshal to seize were declared, the fear of conflict would prove evanescent, for non-resistance is largely a matter of habit and not of principle. If the Supreme Court once declared that a marshal could take property from any person, even a government official, government officials would as readily acquiesce in this decision as they do now, when served with writs of habeas corpus and mandamus.

As has been stated there is a modification of this theory, undoubtedly the result of a compromise between a desire to protect the creditor and a reverence for the theory of sovereign dignity, with also a fear that certain high officials of the government would be more likely to resent interference by a marshal than would lesser employees of the government an private individuals. The leading case is the Davis, ${ }^{57}$ where Justice Miller, following Briggs vs. The Light-

54 Supra, n. 33.

65 The Davis, supra, n. 28. Cf. United States v. Morgan (Circ. Ct. App., 4th Circ., 1900) 99 Fed. 570.

56 Supra, n. 35.

57 Supra, n. 28, but according to the reasoning of the Court in another case, apparently if the marshal obtains possession the shoe is on the other foot, The Willamette Valley (Dist., No. Dist. Cal., 1894) 62 Fed. 293, 305, citing The Davis, supra, n. 28, as authority. This suggests the possibility of a race for possession between the two branches 
boats, ${ }^{88}$ said, "The doctrine is laid down and well supported, that proceedings in rem to enforce a lien against the property of the United States are only forbidden in cases where in order to sustain the proceeding the possession of the United States must be invaded under process of the court." But when is property in the possession of the United States, and when not? In this case the property of the United States was in the possession of the civilian captain of a privately owned merchantman, who agreed to carry for hire. Again in Long vs. The Tampico, ${ }^{59}$ the court decided that the possession of a captain employed to navigate a boat from one port to the other was not the possession of the sovereign. But in the Maipo ${ }^{60}$ the court held that the possession of a captain was the possession of the government. In the first two cases the captain was a private individual, but in the third, had a commission from the Chilean Navy. Was it the captain's gold lace that resulted in a different decision? It was not in his power to bring into opposition to the inarshal the forces of his own government, for he was apparently the only naval officer on the ship, which was in the harbor of a foreign state. It has been suggested, however, that property is in the possession of the government when it is in the possession of one of its officers. ${ }^{61}$ This explanation of the rule makes its practical application no easier. Who is an officer of the government? Is he one declared to be so, or paid in a certain way, or receiving a certain salary, or employed continuously? It seems absurd to deprive a man of a remedy because of the peculiarities of the government's internal organization.

The fear of conflicts between two branches of the government is not a true test. While doubtless there are some officers of the government who would resent interference by a marshal more than others, and there is greater likelihood of the equivalent of a breach of the peace occurring, in the last analysis this is a personal question of the individual and not of his position.

of the government, which would seem quite as undesirable as any attempt by one official to take property from another.

58 Supra, n. 19.

s9 Supra, n. 12 .

60 Supra, n. 2.

61 Long v. The Tampico, supra, n. 12. See The Florence H., supra, n. 5. The unreality of the doctrine is shown by a decision that the possession of officers of the United States revenue marine to complete the contract of a defaulting contractor was not that of the United States but of the contractor, and therefore a libel of a revenue cutter was allowed, The Revenue Cutter No. 2, supra, n. 13. 
Should the rights of the injured person and of the public at large depend on so slight a consideration as the rank of a man doing government work? It does not matter to one whose ship is run down on the one hand, or to the public waiting for the carriage of its goods and the expansion of its trade, on the other, whether the vessel doing the damage is navigated by a rear admiral or by a civilian hired for the job. ${ }^{62}$ While this doctrine has never been repudiated in so many words, the reasoning in a recent case is all against it. $^{\text {Bs }}$

In any event this theory is inconsistent with the others. It leaves out of consideration immunities based on impeccable dignity, that is, - on the sovereign's right to be unfair. It denies the totality of immunity on such grounds by finding it necessary to bring forward another reason. It presupposes liability and dodges the issue of enforcement out of fear of trouble.

(5) Again, it has been argued that an admiralty court could not pass a valid title to government property. This question seems never to have been discussed. Perhaps in those cases where the lien was allowed the government paid before a sale took place. If the objection is based on fear that officers of the State will endeavor to recapture the property, we have again the question of unseemly conflicts; if on the fact that there is no statute authorizing alienation of government property by this method, the answer would seem to be that the admiralty court has power to pass a title to property by reason of the lien upon it, $^{84}$ and that the existence of this power is one of the incidents of the existence of that lien. When a court says there is a lien, it means this power exists, and we are back at the proposition of this article.

(6) Numerous cases, however, do not adopt any of the foregoing theories, but in denying the enforceability, or less often the existence, of a lien, proceed mainly upon the ground that government-owned property, when devoted to the public service, should not be diverted from that service. ${ }^{65}$ The most recent

${ }^{62}$ As in Long v. The Tampico, supra, n. 12.

63 The Roseric, supra, n. 5.

64 E. g. The Trenton, (Dist., E. Dist. Mich., 1880) 4 Fed. 657.

65 The Roseric, supra, n. 5; The F. C. Latrobe, supra, n. 17; The Protector, supra, n. 16; Workman v. New York City, Mayor, Aldermen, and Commonality (1900) 179 U. S. 552, 570, 45 L. Ed. 314, 324, 21 Sup. Ct. Rep. 212, 219; United States v. Morgan, supra, n. 55; The Fidelity, supra, n. 14; The Seneca, supra, n. 16. See 17 Harvard Law Review, 270. Cf. the French law: " $A$ raison de leur utilité, certains navires bien qu'appartenant à des armateurs ne peuvent être saisis. Ce 
decisions lay particular stress upon such reasoning as this. Here we are on firm ground, and this contention has great force in war-time, not only in the case of a public armed ship, but in that of a government merchant vessel, serving a military purpose, or carrying supplies for a civil population, provisioned not by private effort but by that of the State. ${ }^{68}$

However, as has already been stated, there has been recognized a limitation upon this doctrine in cases where government ships are engaged in ordmary commercial trade. In England this limitation seems to have been finally overthrown. ${ }^{67}$ With us, however, there are still numerous unrepudiated suggestions of its compelling force, ${ }^{68}$ bearing the impress of the familiar distinction between the public and commercial functions of a municipal corporation; and certainly the impulse that prompts it in connection with vessels strictly government-owned or operated has also manifested itself in those decisions holding that a vessel operated by a receiver is subject to a lien. ${ }^{.9}$ It is upon this limitation, rather than upon that obtaining as to property not in the actual possession of the government, that the strongest arguments of the proponents of the lien upon our new government owned and civilly operated merchant vessels can be based. It is an argument not without force in the case of domestic vessels, whatever view might be taken as to foreign merchant vessels because of a desire to show international courtesy. Of course, from the point of view of the prospective libelant, the fact that the vessel is on the one hand owned by the state and operated by it, operated by a private person under charter or other arrangement with it, owned by a private person and operated by the government under charter or otherwise, or on the other hand, is owned and operated privately, makes little difference, for he will meet this vessel, not as one meets naval vessels, but in the ordinary commercial channels and will be called upon

sont les navires affectés d̀ un service postal. La saisie empêcherait l'exécution d'un service, et, sauf une exception légale formelle [au cas de contravention douanière] elle est impossible". Edmond Thaller, Traité, etc., de Droit Commercial (Droit Maritime par Georges Ripert), Paris, 1913 , p. $713, \S 892$.

${ }_{66}$ The Roseric, supra, n. 5.

67 The Parlement Belge, supra, n. 7.

68 Supra, n. 38.

${ }^{69} \mathrm{E}$. g. The Willamette Valley, supra, n. 57. Cf. also North American Commercial Co. v. United States (Circ. Ct. App., 9th Circ., 1897) 26 C. C. A. 591, 81 Fed. 748, and cases cited, holding liens enforccable on vessels seized for violation of the navigation laws. 
to deal with it intimately, however owned or operated. This prospective libelant deserves consideration. He must not be disregarded in idealistic and sentimental dreams of government ownership. $\mathrm{He}$ is directly and vitally concerned, far more so than the great mass of the people of this nation, so many of whom live inland, preferring as to maritime matters not directly touching their pockets the self indulgence of visions to practical fairness to the shipping world on the coasts, whose welfare is directly involved. But, on the contrary, protection to the rights of the prospective libelant are by no means the sole desideratum.. A new factor has appeared, which tips the scale the other way,that is, against the enforcement of the lien. Formerly government-owned merchant vessels were an exception, operated for a particular purpose or on isolated runs, and not in pursuance of a programme national in its scope. There are intimations that our new merchant marine may be operated to carry out a national policy. ${ }^{70}$ If so, the amenability of its vessels to seizure here and there will work a serious interruption to the carrying out of a scheme adopted for the benefit of the nation as a whole. It may well be-time only will tell-that the validity and justice of the limitation under discussion will no longer exist in the light of actual conditions.

(7) To return to the last of the seven theories above mentioned: that the lien is an anachronism, and the government can be trusted to do the right thing, Judge Mayer has apparently this faith: "It is not to be presumed, however, that any friendly government, or our own government, will fail to do what is just and fair in connection with operations of a commercial character." Thiers is reported to have said "L'Etat est solvable et honnête homme". ${ }^{22}$ What-has our own State done? There is the Tucker Act, ${ }^{73}$ requiring attendance at Washington for claims over $\$ 10,000$, and there is the limited jurisdiction of the Court of Claims, of which it has been said, paraphrasing a poem of Andrew Marvell:

70 The Nautical Gazette, Jan. 4, 1919, p. 2, Jan. 18, 1919, p. 46, Feb. 15, 1919, p. 115, and supra, n. 1.

71 The Maipo, supra, n. 2.

72 Jèze, Eléments de Droit Public et Administratif, p. 252.

${ }^{73}$ Act of March 3. 1887 , c. 359,24 U. S. Stats. at L. 505 , in large part incorporated in the Judicial Code (Act of March 3, 1911, c. 231, 36 U. S. Stats, at L. 1087). See $\S 24$, par. 20 , and $\S 145$. 
"Had we but world enough and time

This slow procedure were no crime.

We would sit down and think which way

Were best to argue day by day.

Thou by the Indian Ganges' side

Shouldst witness find: I by the tide

Of Humber do the same. I would

Plead with you years before the Flood,

And you should, if you please, refuse

Till the conversion of the Jews.

But at my back I always hear

Time's winged chariots hurrying near;

And yonder all before us lie

Deserts of vast eternity."

With reference to a certain number of cases there is that clause of the Shipping Act," providing: "Such vessels [every vessel purchased, chartered or leased from the United States Shipping Board] while employed solely as merchant vessels shall be subject to all laws, regulations and liabilities of government merchant vessels, whether the United States be interested therein as owner, in whole or in part, or hold any mortgage, lien, or other interest therein." But this would seem to exclude vessels operated by or chartered by the United States Shipping Board. Nor is it clear that the liability to which these vessels are subject is that of privately owned as distinguished from government-owned merchant vessels, nor that the lien is a liability contemplated, nor that if contemplated, is enforceable, nor that the laws, regulations, and liabilities contemplated are merely those of the Navigation Laws relating to registry, inspection, manning and the like, and not to liability to private persons for damage, nor that the rights, if any, given private persons are enforceable elsewhere than in the Court of Claims. In any event questions arising under the Charter $\mathrm{Act}^{75}$ as to government-owned merchant vessels must go to the Court of Claims.

${ }^{74}$ Act of September 7, 1916, c. 451, $\$ 9,39$ U. S. Stats. at L. 728, 730. Upon the whole act see note, 17 Columbia Law Review, 357, and Henry Hall, Regulation of Water Carriers, 66 University of Pennsylvania Law Review, 95.

${ }_{75}$ Act of July 18,1918 , c. 157 . See $\$ 14$. 
To those on the Pacific Coast a trip to Washington and the Court of Claims with regard to a case involving, let us say, not over $\$ 12,000$, is the equivalent of losing it.

Is the lien an anachronism? It is true that it has been traced to an obsolete relic-the law of deodands and the noxas deditio-by a learned author now a Justice of the Supreme Court, ${ }^{76}$ though this theory has been combatted. ${ }^{77}$ But however that may be, and however adverse the current of decision, do not arguments for the existence of a lien or its equivalent obtain today with almost as much force as they ever did? It is true that the owner is more easily reached today than he used to be, and perhaps the reason for the lien based on the difficulty of finding him, contrasted to the ease of catching his ship, has less force. But if he is the government, he is like the great Bogy in Peer Gynt. ${ }^{78}$ On the other hand there is today a greater need for quick decision than formerly, and if there is no lien on merchant vessels governmentally-owned, such quick decision will be seriously interfered with if it be necessary for the prospective libelant to consider in every case whether the innocent-seeming ship he deals with belongs to and is operated by a private individual against whom he has remedies, or is for some reason, possibly obscure, immune.

IV.

What is the remedy for this situation? It depends on the course the government adopts with regard to its many merchant ships, but we may safely assume that a large number will remain owned by the government at least for some time to come.

It is well known that the states of the Australian Commonwealth have for a great number of years conducted enterprises which in other communities have been left to private initiative, and the action of the Parliaments of New South Wales and Queensland, is very significant. Under acts passed there ${ }^{79}$ very full pro-

76 Holmes, The Common Law, p. 25 and ff.

${ }^{77} 1$ Halsbury, Laws of England, p. 61 note, citing Marsden on Collisions (5th ed.) p. 72; 1 Select Pleas in Admiralty, 6 Selden Society Publications lxxii.

${ }_{78}$ Act II, Scene 7.

${ }^{79}$ Claims against the Government and Crown Suits Act, (1912) 9 Statutes of New South Wales No. 27, $\$ 11$, incorporating Claims against Colonial Government Act of 1876. See Quick and Garran, The Annotated Constitution of the Australian Commonwealth, p. 805, $\S 338$, for a statement of remedies against the crown in the Australian Common- 
vision is made for the enforcement of rights against the Crown. Not only can payment of money damages be secured, but specific performance, restitution of rights and recovery of lands and chattels; and, if payment of a money decree against the crown is not made within sixty days after demand, execution may be had for the amount due and may be levied upon any property vested in the state government, though not upon property of the imperial government. The Act of New South Wales came up for consideration in the case of Bowman v. Farnel180 and the motives leading to its passage were thus stated by Judge Faucett: ". . . . when we consider the great variety of transactions which the Colonial government undertakes and carries on, the old maxim [The King can do no wrong] seems in a large degree unapplicable to the state of things existing here and we must presume that the Legislature, having this state of things in view, altered the law to meet the altered circumstances." Nor, apparently, is this process of allowing seizure of property of the state unknown elsewhere. ${ }^{81}$ So far as our merchant marine is concerned, it is quite possible that we are embarking upon the same policy of government ownership that formerly obtained in the Australian Commonwealth, and led to the statutes that I have mentioned. But so far as maritime matters are concerned the remedy of an execution after demand would be without the great advantage of maritime lien. By the time the government had pondered and decided, either the vessel would be gone or possibly the public seriously handicapped by her waiting; and also, if the seizure allowed were merely an attachment, the

wealth. See also Claims against the Government Act, (1911) 29 Vict. No. 23, 1 Queensland Statutes $546, \S 8$, similar in terms to the New South Wales Act, and providing for execution by distress and sale upon any property vested in Her Majesty, except real and personal property used for the land or sea forces or for imperial purposes, or used or intended to be used by the governor, buildings for Parliament of Brisbane, court houses and jails, and property appertaining to them.

so (Sup. Ct. of New South Wales, 1886) 7 N. S. W. L. R. 1, 13, appealed to the Privy Council, where Sir Barnes Peacock spoke to the same effect, Farnell v. Bowman [L. R.] 12 A. C. 643, (1887).

81 Possibly in Italy: by the Codice de Commercio (1882) Art. 7 "the State, the Provinces, and the Communes cannot acquire the status of commercial persons, (la qualità di commercianti), but they can do acts of commerce and for the purposes of these remain subject to the commercial laws and usages." Codice Civile (1865) Arts. 425 to 428, relating to property belonging to the State, the Provinces, the Communes, or private individuals, divides the State's property into the public demesne and patrimonial property, and Italian government merchant vessels would seem to be the latter. In the Code of Civil Procedure, Arts. 585 to 586, listing property exempt from attachment, no mention is made of property 
remedy by sale would be lost, for only the interest of the wrongdoer would pass and not a good title against the world. ${ }^{82}$

An administrative court of the sort popular in many connections might be established. ${ }^{83}$ This would have the advantage of making those who are experts in the carrying out of government policies decide questions they are familiar with. But an objection to this procedure is ably stated by Mr. Laski,-the tendencies of such courts to become bureaucratic and arbitrary. ${ }^{84}$ Conceding, however, the suitability of such a court for deciding questions of rates, ownership and possibly charters, such a court is not needed, might be unfit, and would be overburdened in connection with the great bulk of cases that will arise, concerning wage claims and expenses of care and cure and return of seamen, cargo damage, repairs, supplies, towage, collision, salvage and general average. The District Courts have had long experience in these matters and should continue to decide them.

It is submitted that what is needed is a statute of Congress clearly recognizing liability of government owned or chartered vessels in all these matters to as full an extent as there is liability in the case of merchant vessels privately owned and operated, and jurisdiction to enforce this liability in the District

of the State. The desmesnal property is inalienable under Art. 430 of Codice Civile, but the patrimonial may be alienated in conformity with the laws relating thereto. The Commercial Code, Arts. 674 to 682, relating to privileged claims, makes no exemption of the State's patrimonial property. It would seem that since there is no exemption of the State's patrimonial property it would be liable to attachment, but Art. 430 may be interpreted by the courts as implying an exemption. Only the Giurisprudenza Italiana would show, and it is not available.

Austria: statute promulgating the Law of Executions (1896) says in Art. 8: "in particular there remain unimpaired.... (5) the rules of court decree of May 16, 1793, Collection of Judicial Law, No. 103, limiting the placing of interlocutory orders and judicial execution upon ships intended for the transportation of goverument property in time of war and upon the apparel belonging thereto...." Government ships were probably here included because this citation is one of an inclusive group referring to property including government property which could not be seized. Therefore there is probably government property which could be seized, and arguably government merchant ships carrying war supplies, if any.

Cf. Belgium: garnishee process is permitted against the state, though not a direct seizure of its property, and seizure is permitted of the king's goods if not a suit in personam against him, Errera, Traité de Droit Public Belge, p. 266, § 179, p. $287, \S 194$, p. $192, \S 127$.

82 Supra, n. 64.

$83 \mathrm{Cf}$. Interstate Commerce Commission, and various state railroad commissions, etc.

84 Laski. The Responsibility of the State in England, 32 Harvard Law Review, 447, 462. 
Courts, with an adequate provision for speedily satisfying such decrees as may be rendered. As to the lien, it is quite feasible that the libelant obtain practically the equivalent without holding up the ship. Let Congress provide for the issuance by the Shipping Board of what might be called certificates of immunity. All merchant vessels not carrying these certificates could be proceeded against in the ordinary course. When vessels carrying these certificates were libeled, release of the vessel should be immediately ordered on presentation of the certificate in proper form to the court from which the libel issued, andmost important of all-this process of presentation should be given the same effect as if a stipulation had been filed by the United States to answer to the decree of the court. ${ }^{85}$ It is submitted that this would solve the difficulty as to our own ships in our own courts, but merchant vessels of foreign governments will continue to come to our ports and our own government merchantment will go abroad. By universal treaty provision should be made for extending the practice above outlined to all civilized maritime nations.

Berkeley, California.

Austin Tappan Wright.

so See The Crimdon, supra, n. 3. 